\title{
Bank Support and Export: Evidence from Small Italian Firms*
}

\author{
Francesca Bartoli $^{a} \quad$ Giovanni Ferri $^{b} \quad$ Pierluigi Murro $^{c, \dagger} \quad$ Zeno Rotondi $^{a}$ \\ ${ }^{a}$ UniCredit, Via Marsala 47, 40126 Bologna, Italy \\ ${ }^{b}$ University of Bari, Department of Economics, Via Camillo Rosalba 53, 70124 Bari, Italy \\ ${ }^{c}$ Luiss University, Department of Economics and Finance, Viale Romania 32, 00197 Roma, Italy
}

\begin{abstract}
The ability of a country and its businesses to grow is tightly related to the possibility of exporting and penetrating into foreign markets. The aim of this paper is to study whether bank support can help small businesses (SBs) exporting at the extensive as well as the intensive margin. We address this issue by using a large database on Italian small firms based on a specific designed survey. We provide an empirical analysis of the role of bank support in affecting the firms' export decisions. Our results show that among the exporting SBs those using bank services to support their exports have a higher probability of being better placed in both intensive and extensive margin. More importantly, these positive impacts on export are statistically significant only when the main bank of the firm is an internationalized bank. These results have relevant policy implications as well as consequences for the business models of internationalized banks.

JEL classification: F10; G20

Keywords: Small business finance; Margins of export; Bank-firm relationships; External Finance.
\end{abstract}

\section{Introduction}

In a global economy, export markets are an important venue for firms to grow. In the latest years, against a stagnant domestic economy, the most dynamic firms have sought compensation by internationalizing their sales. However, the literature underlines that internationalizing entails non-trivial investment, which takes the form of sunk costs. To become an exporter, a company must devote resources to identify its specific export market and undertaking the adjustment needed to make its products adequate to that market, tailoring them to local tastes and conforming to the target country's regulations. These sunk costs include, for example, acquiring information about foreign markets, set up distribution networks and customize products to fit local tastes (see, e.g., Baldwin and Krugman, 1989; Dixit, 1989). Furthermore, because most entry costs must be paid up front, potential exporters must have enough liquidity at hand. Hence, the internationalization is much more common for medium to larger-sized enterprises than for smaller-sized businesses (SBs). For these reasons, both theoretical and empirical literature has increasingly recognized the role of financial markets in firms' international orientation and stressed that exports are particularly vulnerable to credit imperfections

\footnotetext{
*We wish to thank participants at the 4th International IFABS Conference held in Valencia in June 2012. Without naming them individually, we thank several experts within UniCredit Group for crucial assistance in constructing the questionnaire as well as for key insights in setting up our analysis. In spite of this, the usual disclaimer applies. Namely, the views put forward in the paper belong exclusively to the authors and do not involve in any way the institutions of affiliation. Pierluigi Murro gratefully acknowledges financial support from UniCredit and University of Bologna, Grant on Retail Banking and Finance.

$\dagger$ Corresponding author. E-mail: pmurro@luiss.it 
(see, e.g., Manova, 2008; Chaney, 2005; Minetti and Zhu, 2011). Though this limitation applies to every country, it makes a straitjacket for the economies that have an industrial structure that consists primarily of SBs. In other words, supporting SBs internationalization would greatly help the growth of these countries.

The aim of this paper is to study whether bank support can help smaller-sized businesses' internationalization. Building on previous literature pertaining to larger-sized enterprises, we take the empirical analysis to a tailor-made database compiled via an extensive survey of over 6,000 Italian SBs (with turnover up to 5 million euros) belonging to various sectors (manufacturing, services, trade and agriculture) conducted by the banking group UniCredit. Our database includes very detailed individual information on firms' internationalization which is based directly on firms' responses to survey questions. Indeed, since these firms were extracted from the loan portfolio of UniCredit Banking Group, the database includes very detailed individual information, such as data on the relationship between firm and banking system or on balance sheet. The available information allows us investigating which features - if any - of the firm-bank relationship help SBs exporting at the extensive as well as the intensive margin. Using a specific question contained in the survey, we identify the businesses availing themselves of a banking support to their exporting activity. In particular, we focus on the SBs that do export and test whether receiving the support of banks increases the probability that SBs export: i) to more than a single foreign market; ii) to more than one geographical export market; iii) to a combination of foreign markets that is more favorable in terms of growth potential; iv) a larger share of their sales.

Our results are in line with our expectations. Namely, among the exporting SBs those effectively using bank services to support their exports have a higher probability of being better placed in all above cases. After accounting for the possible endogeneity of the bank support and controlling for a variety of factors that may also affect export, we find that bank support increase the probability that firms enter in multiple markets, with an estimated average marginal effect of $5.8 \%$. The estimates also suggest that firms that export for a longer time are more likely to increase the number of markets in which they operate. Moreover, the bank support seems to be relevant in explaining the actual number of countries in which firms export. In particular, the support of the main bank has a marginal effect of $11.5 \%$. Finally, the results confirm the role of bank services also for the intensive margin of export: bank support has a positive and significant impact on foreign sales.

The literature suggests that bank internationalization (foreign branches, representative offices abroad) might have a particular role in fostering export propensity (see, e.g., Portes and Rey, 2005). Internationalized banks could have information provider function on the entry market, in addition to a simple financial support. In fact, internationalized banks, thanks to their knowledge of foreign markets, can provide advisory services on counterparty risk assess of local importers or on legal and economic features of local market. In addition they can provide also in loco support, as for instance leasing services, through foreign branches. Our results support this hypothesis. In particular, our findings reveal that the benefit of bank support is stronger when the main bank of the SB is an internationalized bank.

There is growing literature on the role of liquidity constraints on firm export. The theoretical literature emphasizes that export is particularly vulnerable to credit imperfections. For example, Manova (2008) and Chaney (2005) incorporating firm heterogeneity, analyze the impact of financial frictions on different trade margins. Their results imply that financial frictions have sizeable real effects on international flows and 
are important for understanding trade patterns. ${ }^{1}$ However, on firm-level empirical analysis the results are less conclusive about a causality link going from the availability of finance to exports. On one hand, a few studies do find a positive nexus. Bellone et al. (2010) find that exporters have ex-ante a financial advantage vis-à-vis non-exporters on micro-data on France; the finding of Manova (2008) is that credit constraints can explain both the zeros in bilateral trade flows and the variation in the number of products exported as well as countries reached. On the other hand, on data for UK firms, Greenaway et al. (2007) fail to find evidence that new exporters have better financial status than non-exporters. With a specific focus on Italian micro-data, Minetti and Zhu (2011) show that credit rationing significantly depresses the probability of exporting both at the extensive and intensive margin. On the contrary, De Bonis et al. (2008) find that the length of the firm-main bank relationship - where a longer relationship typically lowers the probability of credit rationing - affects the firms' decision to internationalize in the form of FDI and offshoring but not their probability of exporting.

The remainder of the paper is organized as follows. In section 2 we describe the institutional background. Section 3 is devoted to the data description. Section 4 shows the empirical evidence. Section 5 concludes.

\section{The institutional background}

Italy provides an ideal testing ground for study the link between bank support and SBs' export activities. First, the Italian industrial structure is characterized by a large number of small firms which are strongly dependent on loans from local banks to finance their investments and business activity. In 2010, the ratio between the stock market capitalization and the gross domestic product was $15.4 \%$, compared with $117.5 \%$ in the United States (The World Bank, 2012). Moreover, another relevant feature of the Italian banking system is its delimitation within local areas. In practice, according to the Bank of Italy data, more than $90 \%$ of credit granted involves banks and firms located in the same province (Presbitero and Zazzaro, 2011). The central role of local credit market in the financing of investment and export, in conjunction with the strict banking regulation introduced in the late 1930s, allows us to identify exogenous restrictions on the local supply of banking services which can be used as instruments. In fact, as explained in Guiso et al. (2004), until the late 1980s the Italian banking regulation imposed strict limits on the banks' ability to grow and lend.

About export activities, in the last years, the Italian economy displayed a strong increase in export. In particular, the total export in goods was equal to 20.0 billion of dollar in 2000 and to 37.2 billion of dollar in 2010. Among European Union countries, only Germany (104.81 billions) and France (43.58 billions) show an higher value of export in goods. In 2008 , the $4.2 \%$ of Italian firms reported some export activity. The distribution of exporting firms changes depending on firm size. In particular, considering small and medium firms, the percentage of exporting firms was equal to 2.7 for firms with less than 10 employees, to 23.5 for firms with 10 to 19 employees and to 38.9 for firms with 20 to 49 employees.

\footnotetext{
${ }^{1}$ In a different contest, Minetti (2007) suggests that a contraction in bank loans might induce some firms to shift from high quality projects (such as export activities) to low quality projects.
} 


\section{Data and empirical methodology}

\subsection{The empirical strategy}

To verify the role of banks in supporting export activity, we first focus on the extensive margin of exports. The probability that firm $i$ serves more than a single foreign markets can be modeled as:

$\operatorname{Pr}\left(\right.$ Multiple_Markets $\left._{i}=1\right)=\operatorname{Pr}\left(\alpha_{i}+\beta_{1}\right.$ Bank_Support $\left._{i}+X_{i} \gamma_{1}+\varepsilon_{i}>0\right)=\Phi\left(\alpha_{i}+\beta_{1}\right.$ Bank_Support $\left._{i}+X_{i} \gamma_{1}+\varepsilon_{i}\right)$

where $X_{i}$ is a vector of control variables, $\varepsilon_{i}$ is a normally distributed random error with zero mean and unit variance and $\Phi($.$) represents the standard normal cumulative distribution function.$

Bank support to export activity can be potentially endogenous, leading to inconsistent estimates. In fact, export and bank support decisions can be jointly determined. The literature offers predictions on these possible common determinants. These include firm characteristics and local market conditions. A characteristic of a firm that may affect both export and bank support is production efficiency. On the one hand, higher efficiency implies a higher probability of export (Melitz, 2003). On the other hand, higher efficiency increases the likelihood to receive a bank support. Local market conditions may also be a common determinant of export and bank support. For example, tax policy is a determinant of export decisions (Grubert and Mutti, 1991), but also affects firms' corporate financing decisions (MacKie-Mason, 1990). We test the exogeneity of our regressor (and eventually correct it to obtain consistent estimates) by relying on Instrumental Variables (IV) techniques. That is, the probability of using the bank to receive support in exporting is likely to be determined by the characteristics of the local banking system. We model this probability using the following probit:

$$
\operatorname{Pr}\left(\text { Bank_Support }_{i}=1\right)=\operatorname{Pr}\left(I_{p} \delta+X_{i} \lambda+\mu_{i}>0\right)=\Phi\left(I_{p} \delta+X_{i} \lambda\right)
$$

where $I_{p}$ is the vector of instrumental variables and $\mu_{i}$ is a normally distributed error terms with zero mean and unit variance. To ensure the validity of the chosen instruments we have to perform diagnostic checks. We report an F-test of linear restrictions. Under the null hypothesis that instruments are jointly equal to zero, the test statistic is distributed as a chi-squared with one degree of freedom.

Equations (1) and (2) constitute a recursive bivariate probit model. The endogeneity of bank support in equation (1) arises from the possible correlation between the unobserved determinants of firms' export decisions (subsumed in $\varepsilon_{i}$ ) and the unobserved determinants of bank's support (subsumed in $\mu_{i}$ ). Hence, the endogeneity of the instrumented regressor is verified through a Wald test on the probability that the correlation coefficient $\operatorname{corr}\left[\varepsilon_{i}, \mu_{i}\right]$ is equal to zero. The effect of bank support on the probability of exports' geographical diversification can be identified under the assumption that the set of instruments $I_{p}$ are excluded from equation (1). Although Bank support enters equation (1) as an endogenous variable, we can estimate equations (1) and (2) using a standard bivariate probit model (Greene, 2002, pages 715-716).

\subsection{Data description}

The main data source of this paper is the VII UniCredit Survey on SBs, a survey runs by the Italian banking group UniCredit in 2010. Every year this survey gathers data on a sample of Italian firms customers of the bank, having turnover up to 5 million euros. The 2010 wave consists of 6,157 enterprises; interviews were 
carried out between June and September 2010. The sample was designed according to a stratified selection procedure, so that findings are representative at company size level, individual sector level (where the sectors considered are Agriculture, Manufacturing, Services, Trade and Construction), as well as at the territorial level.

The main strength of this database is the very detailed information it collects on individual firms. In particular, the 2010 wave features information regarding the firm's: a) ownership structure, organizational structure and number of employees; b) attitude to innovate; c) extent of internationalization and exports; d) partnership with other firms and whether it is part of a district or a global value chain; e) financial structure and relationships with the banking system. The dataset is obtained by treating a wider record file: we have filtered outliers and misreported cases. The definition of the variables investigated are reported in Table 1.

Table 2 reports the summary statistics for the variables included in the regressions presented in the paper. The geographic distribution of the firms revealed a prominence of the North of Italy (more than $53 \%$ of the total), while other firms were based in the Center (16\%), South and Islands (30\%). By construction of the sample, the average dimension of the firms, measured by the number of the employees, is very small. In particular, the average number of employees is equal to 4.45 , while the median is 2 . Only $17 \%$ of the firms in the sample is a Corporation. On average, in our dataset, the average (median) duration of the bank-firm relationship is 14 (11) years. The sector composition is affected by the nature of the sample. In fact, small firms are usually overrepresented in sectors such as Commerce (31\% of total firms in the sample) and Services (24\%) compared to medium or large firms. Finally, Agricultural, Manufacturing and Construction have almost the same representation in the sample (15\% for each sector). In general, however, the composition is representative for both sample size and shares of the underlying population, so that sector peculiarities should not affect our analyses. Table 3 reports the correlation matrix.

\section{$3.3 \quad$ Export}

The aim of the present work is to empirically verify the role of banking system in supporting export activity. To do this, we focus on two dimensions, conditional on exporting: entry in multiple markets (the "extensive margin" ${ }^{2}$ ), and the export share in turnover (the "intensive margin"). Table 4 provides further details on export activities for the firms in the survey. In particular, the Table shows information about firms' export destinations grouped by geographical area and the amount of foreign sales if the firm exported. Nearly $11 \%$ of the firms in the sample exported in 2010. This percentage is not so small if we consider that exporting firms are only the $4.2 \%$ of the total Italian economy ( $3.3 \%$ if we consider only the SBs segment). As long as export destinations are considered, Table 4 shows that the area of the main European countries (e.g., Germany, France, UK, etc.) is the most popular destination, followed at a long distance by Eastern European Countries ( $77.0 \%$ and $34.9 \%$ of exporters, respectively). If we control for multiple responses, we have that $36.7 \%$ of exporters skip main European countries and sell only to other and more distant foreign markets. Moreover, most firms focus on one (43.9\%) or two $(23.2 \%)$ geographical areas. Average foreign sales of exporting firms accounted for $26.7 \%$ of their total turnover.

\footnotetext{
${ }^{2}$ The extensive margin more rigorously refers to the probability that a firm exports. Even if it can be reasonably argued that the presence of ad hoc banking services affects also this feature, source data and the way we developed the analysis do not allow us to analyze it, since only internationalized firms were asked about bank's services evaluations. Then, we consider the geographical dimension of export activity; namely, the probability that a firm enters multiple markets.
} 
Using these informations, we construct our dependent variables. The first variable we consider is Multiple markets, a basic indicator of geographical diversification of exports. Namely, Multiple markets is a dummy variable taking value one if the firm exports in more than one geographical areas; zero if it focuses in one single geographical area. To further qualify the analysis, we consider as alternative dependent variables Geo, an indicator constructed to take into account the actual number of markets in which each firm operates, ${ }^{3}$ and Geo GDP, that also features the 2010 rate of growth of each geographical area, in order to identify export strategies that are more favorable in terms of growth potential. ${ }^{4}$ Then, we focus on the intensive margin of exports. In this case the dependent variable is the share of export sales over total turnover, taken in logarithm to take into account non-linear effects.

\subsection{Bank support}

Table 5 reports the main institutions that provide support to firms' export activities. Responding to the question "Which of these institutions provide support to your export activity?", $13.5 \%$ of entrepreneurs indicated the banking system, followed by $11 \%$ pointing to Associations, and $8.4 \%$ indicating consultancy firms. Only marginal is the role of finance public holding companies for export promotion such as Simest, Finest, Sace, etc. $(2.8 \%)$, Chambers of commerce $(2.8 \%)$, the Foreign Trade Institute (1.8\%), and the Embassies (1.2\%). So, banks - and especially the internationalized ones - seem to hold a primary position in export enhancing. However, much can still be done: $44.4 \%$ of exporting firms declare they operate autonomously, which may depend on an inbreed tendency of "doing on her own" as well as on lack of information about ad hoc products and services.

About the characteristics of bank services to support small business exports, Table 6 show the firms' evaluations on these services. Beyond ordinary services such as online payments $\left(62.7 \%\right.$, net percentage $\left.{ }^{5}\right)$, credit insurance $(46.0 \%)$ and international guarantees $(31.9 \%)$, the data show that there is a substantial request of advisory services, in the form of counter-parties signaling (30.4\%), legal and financial advisory $(26.7 \%)$, in loco support during fairs $(15.6 \%)$, investment opportunities abroad $(13.1 \%)$ and training services for commercial and administrative personnel (8.8\%). It seems reasonable to suppose that such a support can be provided at best by an internationalized bank.

Considering these data, our key explanatory variable is a dummy variable taking value one if the firm avails itself of the banks in its export activity, zero otherwise. As discussed previously, banks may enhance SBs' export activity by diminishing the entry costs to foreign markets through ad hoc products and services tailored to the needs of this specific segment of firms. Beyond ordinary services, advisory and in loco support are of particular relevance. Since these latter kinds of support are likely to be provided only by a bank having an international network and a specific knowledge of foreign markets, we test the robustness of this hypothesis by controlling for the type of firms' main bank, distinguishing between internationalized banks and domestic banks.

\footnotetext{
${ }^{3}$ Geo is based on answers to the question "Which are the geographical areas of export?", whose results are reported in Table 4. For each item, we constructed a dummy variable taking value one if the firm exports to the area, zero otherwise. Then, we take the average of the ten resulting dummy variables.

${ }^{4}$ Geo GDP is constructed likewise to Geo, with the sole exception that we consider the weighted average of the geographical dummies, where the weights are the rates of GDP growth as of end 2010.

${ }^{5}$ Net percentage calculated as the difference between entrepreneurs who responded "very much" and "enough" and the one who responded "little" and "not al all".
} 


\subsection{Control variables}

We now discuss the other variables included in the regressions. Our set of control variables include several firm's characteristics that are likely to affect exporting behavior. First, we consider the number of years of firm's exporting activity. The literature suggests that the probability of export is a function of prior exporting experience. In fact, can be reasonably argued that overall the cost of entering additional foreign markets could be lower than that involved in entering the first foreign market, because costs can be spread across markets (Roberts and Tybout, 1997). Another important aspect to consider in exporting decisions is the firms' financial health, that may capture the probability of bank support (Greenway et al., 2007). As a measure of firms' credit risk, we use a proxy of the firm's leverage, defined as the logarithm of the ratio of the firm's total loans from the banking system to firm's assets as of end September 2010. Moreover, we include also a variable measuring the relationship between the firm and the banking system, the number of banks with which the firm relates.

A very important factor that we should consider is the size of the firm. Bernand and Jensen (1999) underline that exporters are larger. For this reason, we control for firm size, defined as the logarithm of the firm's employees as of end December 2009, but in addition, we include dummy variables indicating whether a firm is a corporation, it belongs to a partnership, a global value chain or a district. The small size of Italian firms reduces their ability to participate in the global markets. Traditionally, to fill this gap, Italian small firms tended to aggregate in networks, such as strategic partnership, consortium or industrial districts ${ }^{6}$ (Baffigi et al., 1999). In fact, these cooperations may allow a SB to share the distribution network with other small firms and thus face a lower cost for entering foreign markets. We add also a dummy variable taking value one if the firm is family owned and run. There is a growing literature on the internationalization process by family businesses, on its characteristics and outcomes. The final effect of family ownership on the probability of exporting are still not clear (see, e.g., Zahra, 2003; Minetti et al., 2012).

To check for other differences among firms, we include the natural logarithm of age, where the age of the firm is measured as the years since firm's foundation; a territorial dummy variable taking value one if the firm is located in the South of Italy and four sector dummies (Manufacturing, Constructions, Services, and Other). Finally, to better control for local economic and banking development we also include provincial value added as of end December 2009, and the average value of the Herfindhal Hirschman index of concentration on bank loans in the province during 1991-2004 period.

\subsection{Instrumental variables}

In order to tackle endogeneity issues we need an appropriate set of instruments. Our strategy relies on identifying exogenous restrictions in the local supply of banking services. We expect these restrictions to influence directly local banking development and, hence, firms' ability to obtain banks' advisory services specific for export promotion. In contrast, we do not expect these restrictions to affect directly firms' export. In particular, the set of instruments we use in the present empirical analysis are taken from Guiso et al. (2004) and from Herrera and Minetti (2007). In practice, we consider a variable that describes the banking market in 1936, when a strict entry regulation was introduced: the number of saving banks per thousand inhabitants in the region in 1936. Second, following Herrera and Minetti (2007), we use the annual number

\footnotetext{
${ }^{6}$ Industrial districts are communities of small firms acting in spatially concentrated areas and specialized in a specific sector.
} 
of branches created by incumbent banks net of branch closed per thousand inhabitants in the province where the firm is headquartered, taking the average in 1991-2004. Since the number of provinces rose from 95 to 107 over 1991-2006, we impute data on firms headquartered in new provinces referring to their original province. Until the liberalization process in the 1980s, the regulation directly constrained the opening of new branches in the local market, with variable tightness across provinces. Then, the number of branches created plausibly reflects the local tightness of regulation, as well as the banking concentration process. ${ }^{7}$ These variables capture the development of the local banking system, and are unlikely to be correlated with the unobserved firm's characteristics that affect a firm's exporting behavior. Thus, they are used as instruments for bank's support to export activity.

\section{Empirical findings}

\subsection{The extensive margin of export}

As we show in data description, despite the difficulties associated with firm's size, a non trivial part of SBs in our sample engage in export activity. However, because of the difficulties associated with firm's size, exporting is generally confined to one single type of market, which corresponds on most of cases to the main European countries. Given these barriers in terms of sunk costs it would be interesting to examine what role can be played by banks, especially the internationalized ones, in promote SBs' export in multiple markets. Table 7 reports regression results for the probability of export participation in more than one geographical area. Column 1 displays the estimates of equation (1) in which the measure of bank support is treated as exogenous. The list of controls is described in the previous section. We find no evidence that bank support has a statistically significant effect on the probability of entering multiple markets. In the probit estimation, the coefficient of our measure of bank support is -0.171 ; the $z$-statistics is -0.57 . The estimates also suggest that firms that export for a longer time and have bigger size are more likely to increase the number of markets in which they operate. Moreover, the probability of export diversification is lower for firms with higher leverage ratio and for older firms.

The probit estimates are likely to be biased due to the omission of variables that could be correlated with both export and bank support. Instrumental variable estimation allows us to address these issues. In practice, we choose our instruments out of the set of variables reflecting the tightness of the 1936 banking regulation in Italy. Columns 2 and 3 report the results for the bivariate probit model in equation (1) and (2). In particular, column 2 displays the first-stage coefficients on the excluded instruments and on the other variables. The probability of bank support is decreasing in the number of saving bank branches in the province in 1936 and in the number of branches created by incumbents over the 1991-2004 period. Error terms are significantly correlated at less than $10 \%$ confidence level, which confirms that there are missing latent factors affecting both export participation decisions and requests of bank support, hence justifying the estimation of equation (1) and (2) simultaneously. Moreover, the instruments are jointly highly significant $(p$-value $=$ 0.0016), with a first-stage $F$-statistic equals to 9.487 . In column 3 we report the results of IV estimation. After controlling for endogeneity, our indicator of bank support is positive and statistically significant at the $1 \%$ level, with an estimated average marginal effect of $5.8 \%$. This result confirm the hypothesis that bank support increases the probability of firms' export in multiple markets. The reasons behind this positive effect

\footnotetext{
${ }^{7}$ For a detailed discussion on the justification of these instruments, see Herrera and Minetti (2007) and Minetti et al. (2011).
} 
are various. First, the bank support could facilitate the firm's access to more sources of financing that are essential for the export activity of a firm. Second, the banking system, especially internationalized banks, can provide advisory services for export promotion and in loco support that are essential in the choice to export in new markets. Moreover, bank support to export can increase the incentive of the financiers to monitor the firm, increasing firm productivity.

We test the robustness of our findings by considering alternatives and more precise variables of export diversification: Geo and Geo GDP. Since both dependent variables are bounded by construction, we use a Tobit model. In practice, we replace equation (1) with the following equation:

$$
y_{i}=\alpha_{2}+\beta_{2} \text { Bank_Support }_{i}+X_{i} \gamma_{2}+\nu_{i}
$$

where $X_{i}$ is the vector of control variables in equation (1) and $\nu_{i}$ is a normally distributed random error with zero mean and unit variance. Results are reported in Tables 8 and 9 , respectively.

Having defined more rigorously the entry in multiple markets, estimates now suggest a larger positive effect of bank support. This means that the role of a bank in enhancing export activity is not only crucial, but also functional to specific needs associated with specific markets. In particular, Geo and Geo GDP both show an impact of bank support positive and significant at less than $1 \%$ confidence level. Marginal effects allow us to gauge the economic size of these estimates: the bank support has an impact of $11.5 \%$ on Geo and of $51.6 \%$ on Geo GDP. Also the impact of the number of years of export activity has a positive and significant at less than $1 \%$ confidence level, with a marginal effect of $4 \%$ on Geo and of $17 \%$ on Geo GDP.

Since our dependent variables changed, we have to check the exogeneity of Bank support, using an instrumental variable approach. Because the dependent variable is binary, we first obtain fitted probabilities of Bank support from the probit of Equation (2) and then use them as the instruments in the 2SCML Tobit model, that hence results perfectly identified. Unlike the Tobit model where the endogeneity issue is ignored, the estimates from the 2SCML Tobit model, reported in columns 6 and 11, show no evidence that bank support has a statistically significant effect on export diversification. However, the diagnostic tests do not establish the need for an IV approach. In fact, the Wald test of endogeneity for the instrumented regressor cannot be rejected. ${ }^{8}$

\subsection{The role of internationalized banks}

As pointed out above, advisory services for export promotion and in loco support are of particular relevance for SBs. For this reason, support the internationalization of small firms is an objective of many public policy initiatives world-wide. In particular, many public programs are intended to support either the growth of export sales by firms that have done some limited exporting, or the initiation of exporting in new markets by firms that previously only operated in one foreign market. Although these programs are specifically targeted to SBs, there is often a low rate of usage among SB owners and little impact on the trading behaviors of firms that do use the programs (Fischer and Reuber, 2003). The main problem is that small firms are less adept than large firms in accessing government assistance (OECD, 1997).

Very different could be the role of banking system. SBs are used to relate and to receive multiple services (not only financial services) by the banks. Hence, the support of banks with structures in foreign countries

\footnotetext{
${ }^{8}$ Under the null hypothesis that the specified endogenous regressor can actually be treated as exogenous, the test statistic is distributed as a chi-squared with one degree of freedom.
} 
could boost firms' exports in a very effective way. Thanks to their knowledge of foreign markets, banks could advise their customers about business opportunities abroad and foreign regulations (Beretta et al., 2005). To examine this issue we split the sample into two sub-samples, with respect to the type of firm's main bank, distinguishing between internationalized and local banks. Having verified the exogeneity of Bank support with respect to export diversification, we then re-estimate equation (3) for each sub-sample. Columns 7-8 and 12-13 confirm our view: the role of the bank in enhancing export activity is positive and significant (at less than $5 \%$ confidence level) only in the case of an internationalized bank, which is the only that can provide services like advisory or in loco support, that are crucial to enter distant markets. ${ }^{9}$ The empirical analysis confirm the theoretical prediction that there is a positive relationship between bank internationalization and export propensity.

\subsection{The intensive margin of export}

In this section, we investigate the role of banks on the intensive margin of exports by looking at the effect of bank support on foreign sales, defined as the ratio of exports over turnover, taken in logarithm to account for non linear effects. Since the dependent variable is bounded by construction between 0 and 100 , we use also in this case the Tobit model represented by equation (3). We also control for the endogeneity of bank support but the diagnostic tests do not establish the need for an IV approach.

Results, reported in Table 10, confirm the role of bank services also for the intensive margin of export: bank support has a positive and significant impact on foreign sales (at 10\% confidence level), with a marginal effect equal to $10.3 \%$. This impact is stronger if we focus on the internationalized bank subsample: now bank support turns out to be significant at less than $1 \%$ confidence level, with a marginal effect on export turnover of $18.2 \%$. Thus, the services provided by internationalized banks not only are more effective than those provided by locally based banks in enhancing the probability of entry in multiple markets, but are also conducive to a higher intensity of exports. ${ }^{10}$

\section{Conclusions}

To overcome the slack dynamics of domestic demand, firms can try to empower their exports. However, exporting entails sunk costs - investments to tailor products and distribution chains to the specificity of each foreign market that would be lost the moment the firm ceases exporting there - and special financial needs - shifting (often intangible) assets abroad aggravates the asymmetry of information vis-à-vis lenders - that may pose gravest problems to small-sized businesses. This paper belongs to the wide literature on the effects of finance for international trade. Using a unique database on a large sample of individual firms representative of the productive stratum with less than 5 million euro turnover, we verified whether bank support does help firms exporting. Specifically, we tested whether bank support affects the probability that a firm: i) exports to more than one market - with respect to the baseline case of a firm exporting to a single market, which would make exporting more fragile to negative shocks in a single market; and/or ii) exports to more than one geographical area - thus denoting a more sophisticated exporting attitude with respect to firms exporting to fewer foreign markets; and/or iii) exports to a combination of foreign markets that is

\footnotetext{
${ }^{9}$ The domestic bank estimate reported in columns 8 and 13 may however be affected by small sample bias.

${ }^{10}$ Again, it should be noted that the local bank estimate reported in columns 18 may be affected by small sample bias.
} 
more favorable in terms of growth potential - thus being better positioned to reap the benefits of expanding demand for its exports. In addition, we also verified whether bank support impacts firms' exports at the intensive margin - i.e. it is conducive to exporting a larger share of firm's sales.

Without exception, we found that bank support significantly boosts SBs' exporting activity at both the extensive and intensive margin. Furthermore, and not surprisingly, in all the cases considered the results are stronger when the firm's main bank is itself internationalized. Our results bring some hope to the debate about economic stagnation. Even though the largest European banks invested in a retail network abroad on the basis of their autonomous business decisions - in view of the profitability of those activities per se - the fact that now they possess this foreign network seems to enable them to play an important role to boost the export potential of SBs, thus improving the growth potential of the national economies.

\section{References}

[1] Baffigi, A., Pagnini, M., Quintiliani, F. (1999). Industrial Districts and Local Banks: Do the Twins Ever Meet?. Working paper, 347, Bank of Italy.

[2] Baldwin, R., Krugman, P.R. (1989). Persistent trade effects of large exchange rate shocks. Quarterly Journal of Economics 104(4), 635-654.

[3] Bellone, F., Musso, P., Nesta, L., Schiavo, S. (2010). Financial Constraints and Firm Export Behaviour. World Economy 33(3), 347-73.

[4] Beretta, E., Del Prete, S., Federico, S. (2005). Bank internationalization and export propensity: an analysis on Italian provinces. In L.F. Signorini (Ed.), Local economies and internationalization in Italy, Bank of Italy, Rome.

[5] Bernard, A.B., Jensen, B.J. (1999). Exceptional exporter performance: cause, effect, or both?. Journal of International Economics 47, 1-25.

[6] Chaney, T., 2005. Liquidity Constrained Exporters. University of Chicago, mimeo.

[7] De Bonis, R., Ferri, G., Rotondi, Z. (2008). Do bank-firm relationships influence firm internationalization?. MO.FI.R. Working Papers 37.

[8] Dixit, A. (1989). Entry and Exit Decisions Under Uncertainty. Journal of Political Economy 97(3), 620-638.

[9] Fischer, E., Reuber, A.R. (2003). Targeting Export Support to SMEs: Owners' International Experience as a Segmentation Basis. Small Business Economics 20, 69-82.

[10] Greenaway, D., Guariglia, A., Kneller, R. (2007). Financial factors and exporting decisions. Journal of International Economics 73(2), 377-395.

[11] Greene, W. (2002). Econometric Analysis. Prentice Hall, Upper Saddle River, New Jersey.

[12] Grubert, H., Mutti J. (1991). Taxes, Tariffs and Transfer Pricing in Multinational Corporate Decision Making. Review of Economics and Statistics 73, 285-293.

[13] Guiso, L., Sapienza, P., Zingales, L. (2004). Does local financial development matter?. Quarterly Journal of Economics, 119, 929-969.

[14] Herrera A.M, Minetti, R. (2007). Informed finance and technological change: evidence from credit relationship. Journal of Financial Economics 83, 223-269.

[15] MacKie-Mason, J.K. (1990). Do Taxes Affect Corporate Financing Decisions?. Journal of Finance 45, 1471-1493.

[16] Manova, K. (2008). Credit Constraints, Heterogeneous Firms and International Trade. NBER Working Paper 14531 . 
[17] Melitz M. (2003). The impact of trade on intra-industry reallocations and aggregate industry productivity. Econometrica 71(6), 1695-725.

[18] Minetti, R. (2007). Bank capital, firm liquidity, and project quality. Journal of Monetary Economics $54(8), 2584-2594$

[19] Minetti, R., Murro, P., Paiella, M. (2011). Ownership structure, Governance, and Innovation: Evidence from Italy. DES-Discussion Paper, No. 1/2011.

[20] Minetti, R., Murro, P., Zhu, S.C. (2012). Corporate Governance and Firm Internationalization. Michigan State University, mimeo.

[21] Minetti, R., Zhu, S.C. (2011). Credit constraints and firm export: Microeconomic evidence from Italy. Journal of International Economics 83, 109-125.

[22] OECD (1997), Globalisation and Small and Medium Enterprises (SMEs). Volume 1: Synthesis Report and Volume 2: Country Studies, Paris: Organisation for Economic Co-operation and Development.

[23] Portes, R., Rey, H. (2005). The determinants of cross-borderequity flows. Journal of International Economics 65, 269-296.

[24] Presbitero, A., Zazzaro, A. (2011). Competition and relationship lending: Friends or foes?. Journal of Financial Intermediation 20, 387-413.

[25] Roberts M.J., Tybout J.R. (1997). The decision to export in Colombia: An empirical model of entry with sunk costs. American Economic Review 87 (4), 545-564.

[26] The World Bank (2012). Market capitalization of listed companies (\% of GDP). http://data.worldbank.org/indicator/CM.MKT.LCAP.GD.ZS.

[27] Zahra, S.A. (2003). International expansion of U.S. manufacturing family businesses: the effect of ownership and involvement. Journal of Business Venturing 18, 495-512. 


\section{Appendix}

Table 1. Variables: definition and source

\begin{tabular}{|c|c|}
\hline Variable & Definition and source (in parentheses) \\
\hline Multiple markets & $\begin{array}{l}\text { Dummy variable taking value } 1 \text { if the firm exports in more than one geographical area, } 0 \text { if it } \\
\text { exports in one geographical area. (UniCredit Survey on SBs) }\end{array}$ \\
\hline Geo & $\begin{array}{l}\text { Indicator of export diversification constructed as to take into account the actual markets in which } \\
\text { each firm operates. (UniCredit Survey on SBs) }\end{array}$ \\
\hline Geo GDP & $\begin{array}{l}\text { Indicator of export diversification constructed as to take into account the actual markets in which } \\
\text { each firm operates and the rate of growth of these markets. (UniCredit Survey on SBs) }\end{array}$ \\
\hline Foreign sales & Log of exports' turnover over total turnover. (UniCredit Survey on SBs) \\
\hline Internationalized bank & $\begin{array}{l}\text { Dummy variable taking value } 1 \text { if the firm's main bank is an internationalized bank, } 0 \text { otherwise. } \\
\text { (UniCredit Survey on SBs) }\end{array}$ \\
\hline Domestic bank & $\begin{array}{l}\text { Dummy variable taking value } 1 \text { if the firm's main bank is a domestic bank, } 0 \text { otherwise. } \\
\text { (UniCredit Survey on SBs) }\end{array}$ \\
\hline Bank Support & $\begin{array}{l}\text { Dummy variable taking value } 1 \text { if the firm leans to the bank in its export activity; } 0 \text { otherwise. } \\
\text { (UniCredit Survey on SBs) }\end{array}$ \\
\hline Export years & Numbers of years of firm's export activity. (UniCredit Survey on SBs) \\
\hline Leverage & $\begin{array}{l}\text { Log of the ratio of firm's total used loans from the banking system to firm's assets as of end } \\
\text { September 2010. (Italian Credit Register) }\end{array}$ \\
\hline Banks & Dummy variable taking value 1 if the firm has multiple banks. (UniCredit Survey on SBs) \\
\hline GDP & Provincial GDP as of end December 2009. (Italian National Statistic Office) \\
\hline Herfindhal & $\begin{array}{l}\text { Average value of the Herfindhal Hirschman index of concentration on bank loans in the province } \\
\text { during 1991-2004 period. (Bank of Italy) }\end{array}$ \\
\hline Age & Log of the firm's age as of end September 2010. (UniCredit Survey on SBs) \\
\hline Size & Log of the firm's number of employees as of end December 2009. (UniCredit Survey on SBs) \\
\hline Global value chain & $\begin{array}{l}\text { Dummy variable taking value } 1 \text { if the firm belongs to a global value chain; } 0 \text { otherwise. } \\
\text { (UniCredit Survey on SBs) }\end{array}$ \\
\hline District & $\begin{array}{l}\text { Dummy variable taking value } 1 \text { if the firm belongs to a districts; } 0 \text { otherwise. (UniCredit Survey } \\
\text { on SBs) }\end{array}$ \\
\hline Partnership & $\begin{array}{l}\text { Dummy variable taking value } 1 \text { if the firm has partnerships with other firms or institutions, } 0 \\
\text { otherwise. (UniCredit Survey on SBs) }\end{array}$ \\
\hline Corporation & $\begin{array}{l}\text { Dummy variable taking value } 1 \text { if the firm is a limited liability company; } 0 \text { otherwise. (UniCredit } \\
\text { Survey on SBs) }\end{array}$ \\
\hline Family & $\begin{array}{l}\text { Dummy variable taking value } 1 \text { if the firm is family owned and run; } 0 \text { otherwise. (UniCredit } \\
\text { Survey on SBs) }\end{array}$ \\
\hline Manufacturing & $\begin{array}{l}\text { Dummy variable taking value } 1 \text { if the firm belongs to the Manufacturing industry; } 0 \text { otherwise. } \\
\text { (UniCredit Survey on SBs) }\end{array}$ \\
\hline Constructions & $\begin{array}{l}\text { Dummy variable taking value } 1 \text { if the firm belongs to the Constructions industry; } 0 \text { otherwise. } \\
\text { (UniCredit Survey on SBs) }\end{array}$ \\
\hline Services & $\begin{array}{l}\text { Dummy variable taking value } 1 \text { if the firm belongs to the Services industry; } 0 \text { otherwise. } \\
\text { (UniCredit Survey on SBs) }\end{array}$ \\
\hline Other & $\begin{array}{l}\text { Dummy variable taking value } 1 \text { if the firm belongs to the Other sector industry; } 0 \text { otherwise. } \\
\text { (UniCredit Survey on SBs) }\end{array}$ \\
\hline South & $\begin{array}{l}\text { Dummy variable taking value } 1 \text { if the bank branch where the credit relationship with the firm } \\
\text { takes place is located in South Italy; } 0 \text { otherwise. (UniCredit Survey on SBs) }\end{array}$ \\
\hline Saving banks & Number of saving banks per thousands inhabitants in the region in 1936. (Bank of Italy) \\
\hline $\begin{array}{l}\text { New branches by } \\
\text { incumbents }\end{array}$ & $\begin{array}{l}\text { Average value of the annual number of branches created by incumbent banks net of branches } \\
\text { closed in the province where the firm is headquartered, per thousand inhabitants, during the } \\
\text { 1991-2004 period. (Bank of Italy) }\end{array}$ \\
\hline
\end{tabular}


Table 2. Summary statistics

\begin{tabular}{|c|c|c|c|c|c|}
\hline Variables & Observations & Mean & $\begin{array}{c}1 \text { st } \\
\text { Percentile }\end{array}$ & $\begin{array}{c}\text { 99th } \\
\text { Percentile }\end{array}$ & $\begin{array}{c}\text { Standard } \\
\text { Deviation }\end{array}$ \\
\hline \multicolumn{6}{|l|}{ Dependent Variables } \\
\hline Multiple markets & 661 & 0.5477 & 0.0000 & 1.0000 & 0.4981 \\
\hline Geo & 6157 & 0.0245 & 0.0000 & 0.5000 & 0.0918 \\
\hline Geo GDP & 6157 & 0.0908 & 0.0000 & 2.1129 & 0.3970 \\
\hline Foreign sales ( $\%$ on total sales) & 812 & 26.582 & 0.0000 & 2.0000 & 24.952 \\
\hline \multicolumn{6}{|l|}{ Endogenous Variables } \\
\hline Bank Support & 681 & 0.1351 & 0.0000 & 1.0000 & 0.3420 \\
\hline \multicolumn{6}{|l|}{ Control Variables } \\
\hline Internationalized bank & 6157 & 0.8122 & 0.0000 & 1.0000 & 0.3905 \\
\hline Domestic bank & 6157 & 0.0814 & 0.0000 & 1.0000 & 0.2734 \\
\hline Export years & 1049 & 2.7874 & 1.0000 & 4.0000 & 1.1874 \\
\hline Leverage & 6157 & 30.033 & 1.0000 & 100.00 & 21.4199 \\
\hline Banks & 6157 & 0.5545 & 0.0000 & 1.0000 & 0.4970 \\
\hline GDP & 6143 & 0.0721 & -0.0406 & 0.2071 & 0.0320 \\
\hline Herfindhal & 6143 & 0.0798 & 0.0332 & 0.1979 & 0.0368 \\
\hline Age & 5978 & 17.492 & 1.0000 & 71.000 & 14.878 \\
\hline (ln) Age & 5978 & 2.5161 & 0.0000 & 1.8451 & 0.8897 \\
\hline Number of employees & 6157 & 4.4570 & 0.0000 & 32.000 & 6.8695 \\
\hline Size & 6157 & 0.9931 & 0.0000 & 1.5052 & 0.9137 \\
\hline Relationship length & 6157 & 13.960 & 1.0000 & 51.000 & 11.110 \\
\hline Global value chain & 6157 & 0.0853 & 0.0000 & 1.0000 & 0.2793 \\
\hline District & 6157 & 0.2353 & 0.0000 & 1.0000 & 0.4242 \\
\hline Partnership & 6157 & 0.4713 & 0.0000 & 1.0000 & 0.4992 \\
\hline Corporation & 6157 & 0.1743 & 0.0000 & 1.0000 & 0.3794 \\
\hline Family & 6157 & 0.2287 & 0.0000 & 1.0000 & 0.4200 \\
\hline North West & 6157 & 0.2478 & 0.0000 & 1.0000 & 0.4317 \\
\hline North East & 6157 & 0.2889 & 0.0000 & 1.0000 & 0.4533 \\
\hline Center & 6157 & 0.1625 & 0.0000 & 1.0000 & 0.3690 \\
\hline South & 6157 & 0.3006 & 0.0000 & 1.0000 & 0.4586 \\
\hline Manufacturing & 6157 & 0.1501 & 0.0000 & 1.0000 & 0.3571 \\
\hline Construction & 6157 & 0.1543 & 0.0000 & 1.0000 & 0.3612 \\
\hline Services & 6157 & 0.2405 & 0.0000 & 1.0000 & 0.4274 \\
\hline Other & 6157 & 0.1405 & 0.0000 & 1.0000 & 0.3475 \\
\hline \multicolumn{6}{|l|}{ Instrumental Variables } \\
\hline Saving banks & 6143 & 0.2547 & 0.0000 & 1.6119 & 0.3624 \\
\hline New branches by incumbents & 6143 & 15.458 & 1.6923 & 88.615 & 16.823 \\
\hline
\end{tabular}




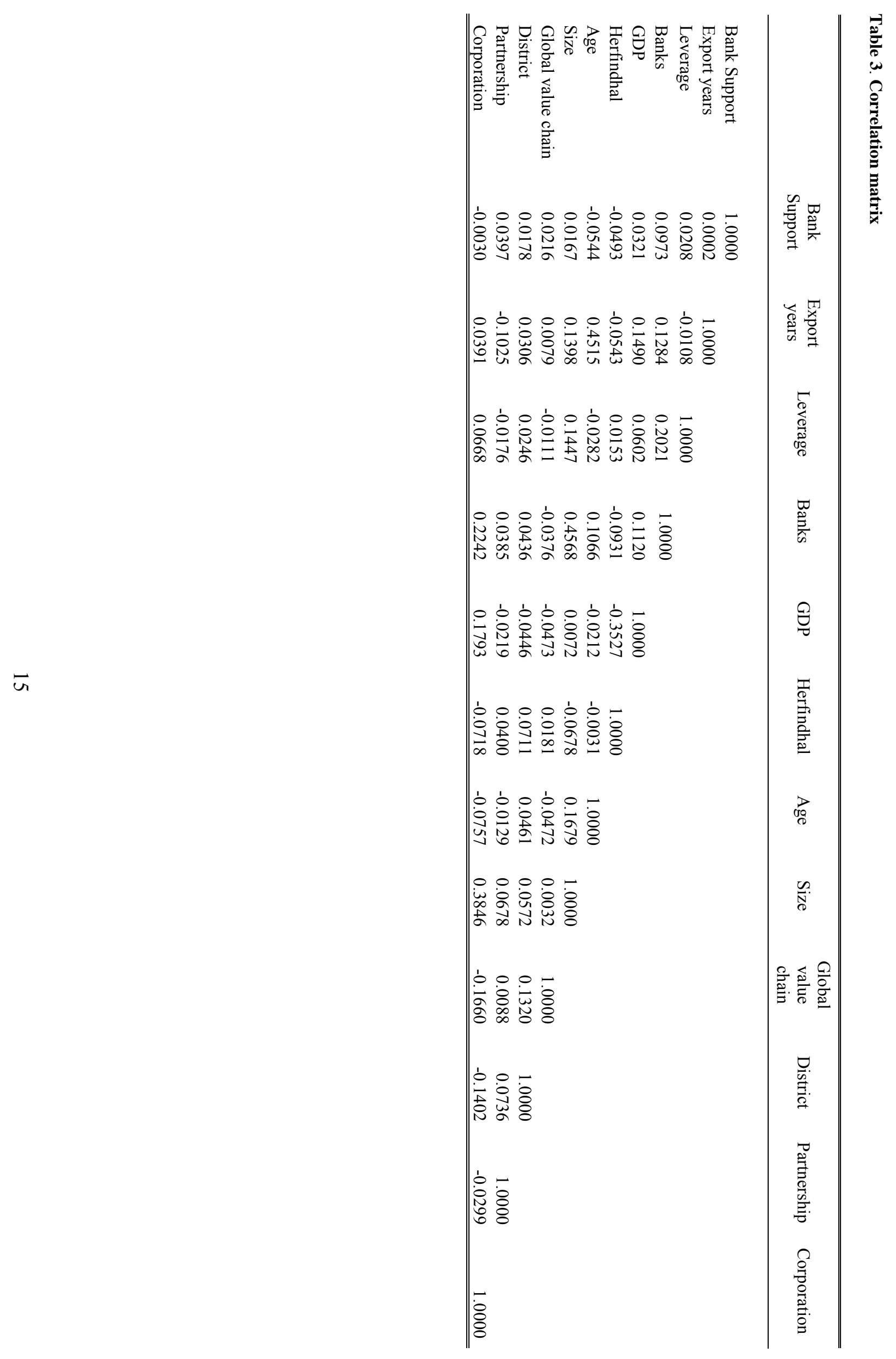


Table 4. Which are the geographical areas you export to?

\begin{tabular}{lr}
\hline & Percentage \\
\hline Main European countries & $77.7 \%$ \\
Eastern Europe (new EU members, Balkans and Russia) & $34.9 \%$ \\
Middle East and North Africa & $20.6 \%$ \\
Northern America & $18.4 \%$ \\
Middle and South America & $15.0 \%$ \\
Other Asian countries & $14.2 \%$ \\
China, India & $13.7 \%$ \\
Scandinavian countries & $13.1 \%$ \\
Sub-Saharan Africa & $7.8 \%$ \\
Oceania & $6.3 \%$ \\
\hline & \\
\hline One single market & $43.9 \%$ \\
Two markets & $23.2 \%$ \\
From three to five markets & $23.8 \%$ \\
Other - Do not know - not indicated & $2.9 \%$ \\
\hline \hline
\end{tabular}

Note: Multiple responses; total respondents: 681.

Table 5. Which of these institutions provide support to your export activity?

\begin{tabular}{lr}
\hline \multicolumn{1}{c}{ Variables } & Percentage \\
\hline Banks & $13.5 \%$ \\
Associations & $11.0 \%$ \\
Consultancy firms & $8.4 \%$ \\
Other public Institutions (Ministries) & $2.9 \%$ \\
Finance public holding companies for export promotion & \\
(e.g., Simest, Finest, Informest, Sace, etc ...) & $2.8 \%$ \\
Chamber of commerce & $2.6 \%$ \\
ICE (Foreign Commerce Institute) & $1.8 \%$ \\
Embassies & $1.2 \%$ \\
Nobody & $44.4 \%$ \\
Other - Do not know - not indicated & $11.5 \%$ \\
\hline \hline
\end{tabular}

Note: total respondents: 681 . 


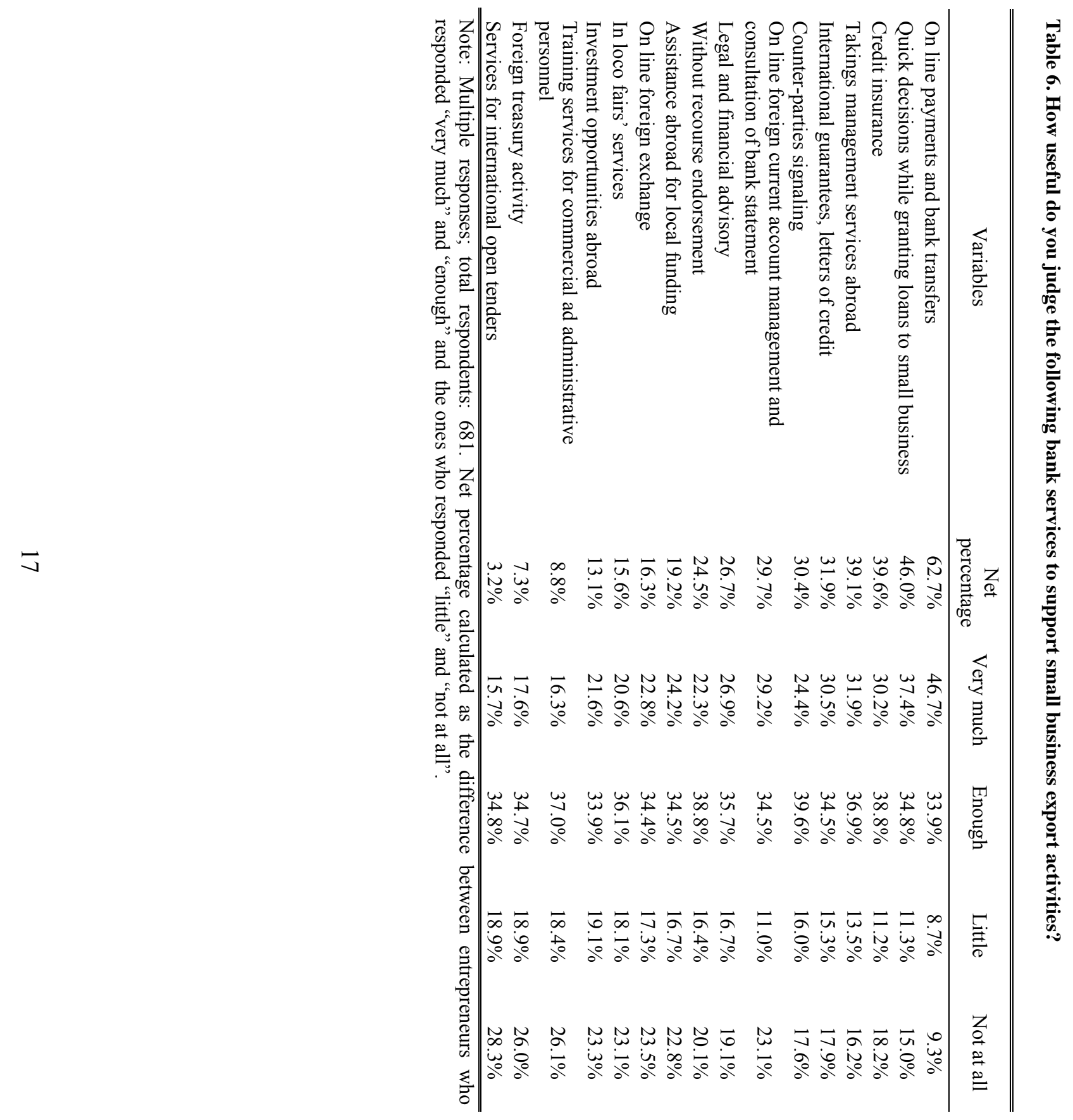




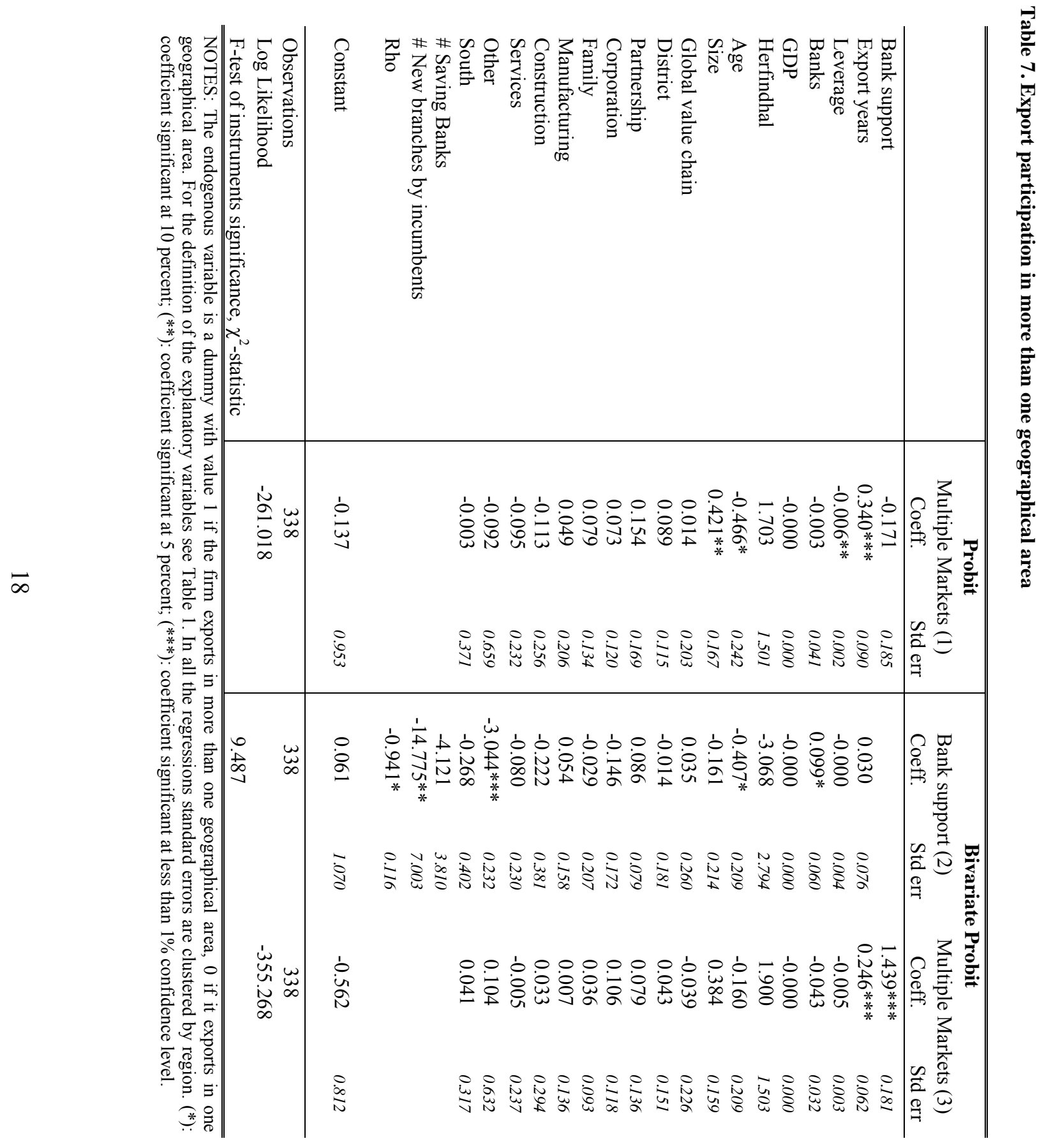




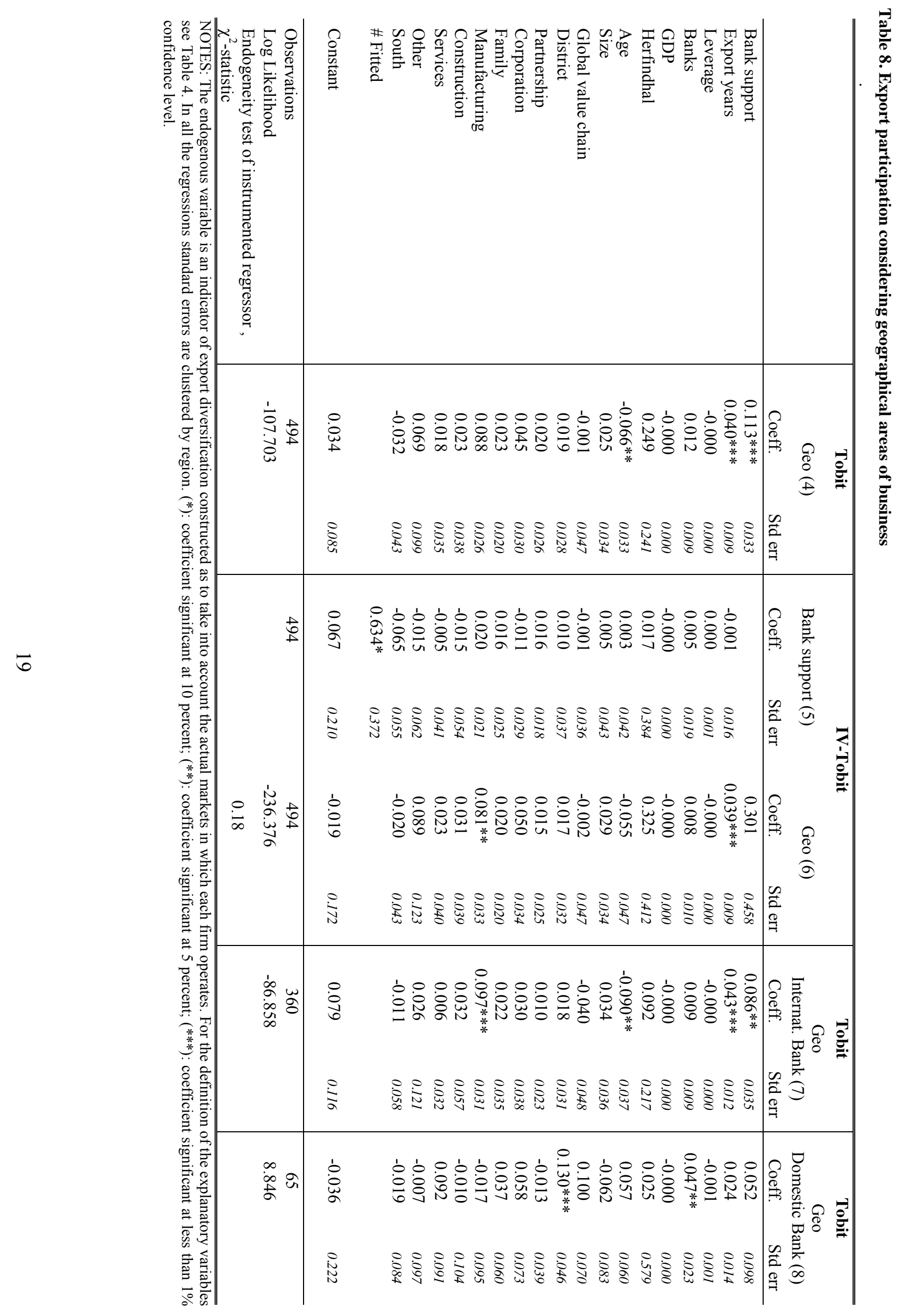




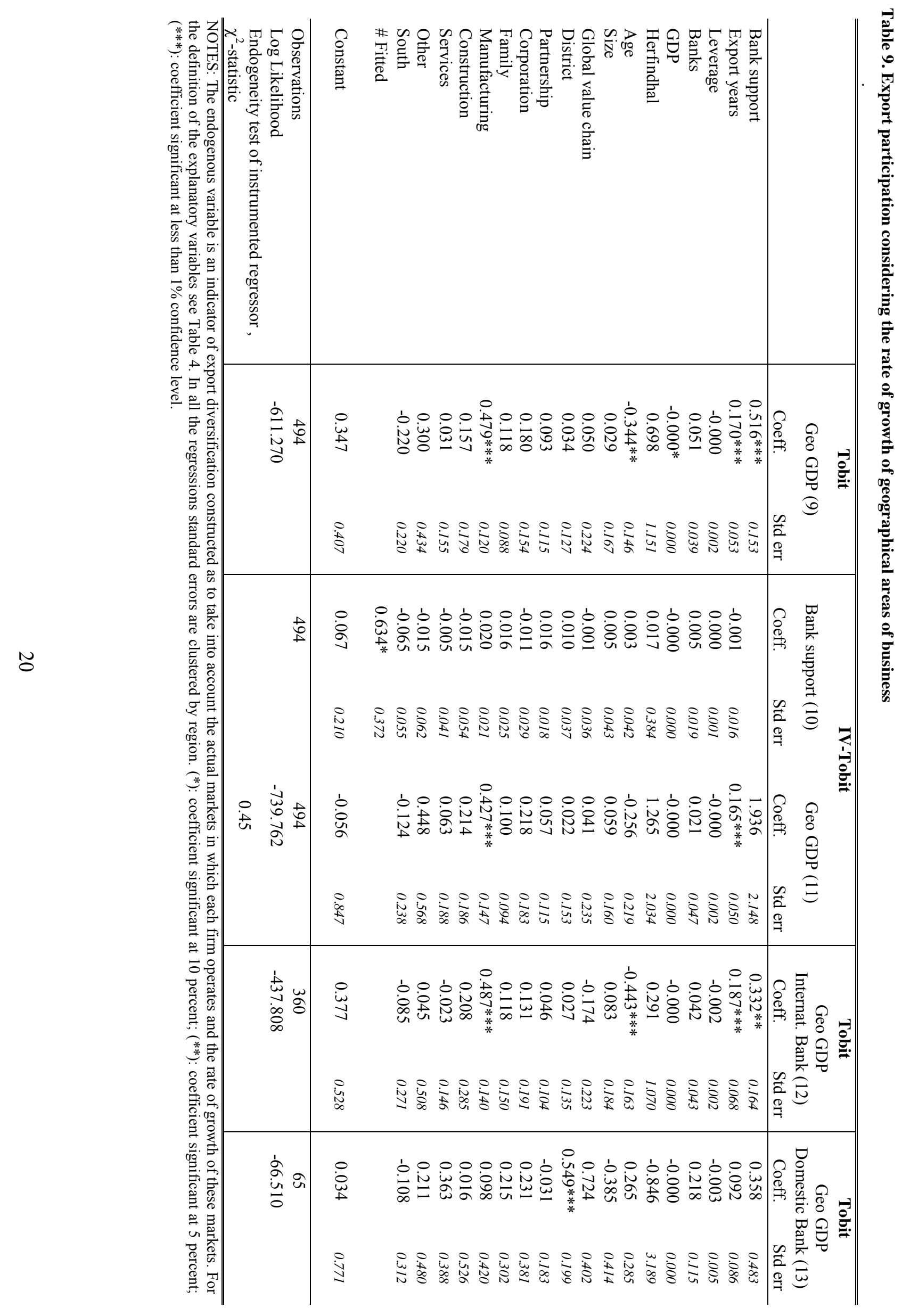




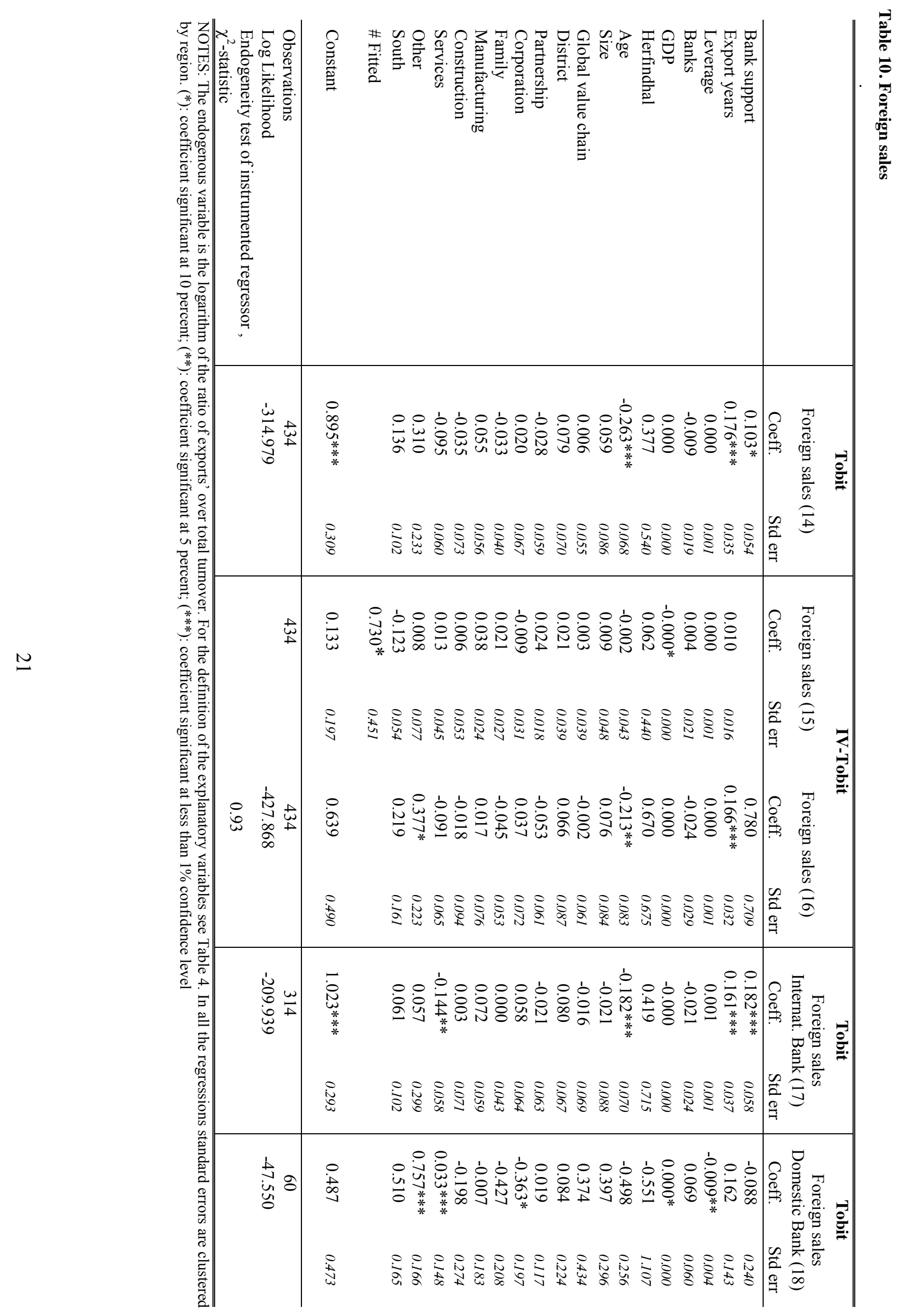

